\title{
Monika Piosik*
}

Adam Mickiewicz University

ORCID: 0000-0002-4334-2532

\section{THE CRISIS OF RELIGIOUS INTOLERANCE IN CONTEMPORARY INDONESIA - A PHENOMENON OF THE ISLAMIC HOUSING INDUSTRY AND ITS IMPACT ON SOCIAL LIFE}

\begin{abstract}
In the last few years Indonesia has been experiencing a new wave of Muslim revival. In addition to the growing popularity of conservative and even radical Muslim ideologies such as Wahhabism and Salafism, this de facto multi-religious society is facing a strong trend towards religious segregation. Indonesians are looking for new forms of their religious manifestation and expressions of their piety. One of the most vivid examples of Muslim separation from other religions is the perumahan syariah, a new form of gated communities in Indonesia. The article describes the growing phenomenon of closed neighborhoods where residents' lives are restricted by Sharia law. The paper first describes the roots of the current religious revival and its impact on the social situation, then deepens the definition of gated communities in the context of perumahan syariah as well as controversies linked to the topic. In conclusion, the possible implications for social life in Indonesia are presented.
\end{abstract}

Keywords: Indonesia, gated communities, anthropology, Islam, radicalization

\section{INTRODUCTION}

In recent years Indonesia, the most populous Muslim country in the world, has been facing a growing crisis of religious intolerance. Although the Constitution of the Republic of Indonesia officially recognizes five religions ${ }^{1}$, there are approximately 220 million Muslims (Indonesia...) and they constitute a majority that has a real impact on the social and political life of the country. When General Suharto's regime ended in 1998, Indonesians opened up to the world, taking on both the positive and negative sides of globalization. Not only modern technologies and liberal ideas but also radical movements began to flow into the country.

* Corresponding author: Monika Piosik, Uniwersytet im. Adama Mickiewicza, Wydział Antropologii i Kulturoznawstwa UAM, ul. Wieniawskiego 1,61-712 Poznań; e-mail: piosik.monika@gmail.com.

1 Indonesia officially recognizes six faiths: Islam, Protestantism, Catholicism, Hinduism, Buddhism, and Confucianism. 
With them, society is changing, although Indonesia has so far been an example of peaceful coexistence of democracy and Islam. Islam itself in Indonesia has been seen as moderate, tolerant and mystical.

Muslim movements in Indonesia, including the two largest Islamic organizations in the world, Nahdlatul Ulama and Muhammadiyah, face the great challenge of maintaining pluralism in the country, but their relationship with modernity and dynamic urbanization is questionable. It is becoming increasingly clear that religious tolerance in Indonesia applies particularly to Muslims. Both Christians and Hindus encounter discrimination on a daily basis. The case of a Buddhist woman who was supposedly complaining about calls for prayer being too loud has had a great impact on the international arena. The woman was accused of blasphemy and sentenced to 18 months in prison (Llewellyn 2019). As the pious Muslim way of life is becoming more widespread and public space for Islam is being seized, religious minorities are enjoying less and less freedom.

Perumahan syariah, also called perumahan islamor kampung islam is a current phenomenon and raising trend that is deepening social divisions in Indonesia. Gated communities exist in enclosed urban areas, functioning according to the principles of Sharia. In itself, the phenomenon of perumahan syariah in Indonesia is a well-known concept of buying property linked to Islamic economics. Islamic mortgages are mortgages granted according to Shariah rules. One of the advantages of Sharia mortgages is the amount of fixed mortgage installments until the end of the loan period. This differs from traditional mortgages, where the amount of an installment may increase or decrease with changes in the loan interest rate. Since the Islamic banks do not benefit from the interest rule, the number of installments remains constant until the end of the loan period. This condition is beneficial for the borrower, who does not have to worry that the monthly installments will suddenly increase (Firmansyah and Gunardi 2016: 314-315).

Nowadays, perumahan syariah is gaining in importance also as a cultural phenomenon, arousing interest among anthropologists, although not many papers have been published. In this article I will therefore partially present the results of my fieldwork conducted from July to September 2018. I conducted in-depth interviews with residents of different faiths in the city of Malang in East Java Province. Interviews were held in both the English and Indonesian languages. A group of my interlocutors were associated with the academic community in Malang. Each of them recommended another person to me (snowball sampling), although they did not necessarily have a close relationship. Very often they were working together in universities, not always in the same department. Most of them were members of Nahdlatul Ulama, while one was of Muhammadiyah, and three were Christians and one Hindu.

Thanks to the courtesy of my interlocutors I had the opportunity to visit one of the settlements called perumahan Islam, although only four of them were residents. In order to maintain the anonymity of my interlocutors, I decided not to disclose the name of the settlement I have visited, as it is a recognizable and relatively small community. Most of my thirty interlocutors expressed their views on the topic of perumahan syariah. I use their statements as secondary sources. In the first part, I will focus on the new wave of religious intolerance in Indonesia, its causes, and manifestations in everyday life. Next, I will present the phenomenon of perumahan syariah, which is one of the most vivid examples of religious segregation 
The crisis of religious intolerance in contemporary Indonesia...

in contemporary Indonesia. In conclusion, I will analyze this dynamic phenomenon and its possible social consequences in the long-term perspective.

\section{THE ROOTS OF INTOLERANCE}

After more than 20 years of Indonesia building a free and democratic state, despite the westernization of many areas of everyday life, religion, especially Islam, plays very influential role in the country. For Saudi Arabia, traditionally seen as the patron of the Islamic world, Indonesia has become an important point on the map. The growing number of Muslims in Southeast Asia is clearly moving the centre of the Islamic world from the Arabian Peninsula even further east. The Saudis, aware of this process, are trying to maintain their traditional status. One of the most common ways of promoting the conservative, Saudi Arab version of Islam is large-scale investment in the education sector as well as public health (Kovacs 2014). Through numerous scholarships and funding of school and hospital facilities, the Saudis are effectively increasing their influence in the Malay Archipelago. Thanks to that, Salafism, the conservative Islamist branch, has been gaining support and popularity in Indonesia, leading directly to a significant crisis of religious tolerance. Liberalization processes have clearly slowed down.

The promotion of conservative branches combined with the inflow of capital results in bottom-up radicalization, which brings about visible changes, including the weakening of liberal influences in the region. Islam in Indonesia has become an important political tool for the authorities to effectively manipulate public sentiment. Although Indonesia has been going through a process of democratization since the late 1990s, the current tendency to Islamize politics raises doubts about the prospects for pluralism and secularization of the state. There is concern that the Muslim religious revival may threaten social and cultural diversity. The current trend to loudly manifest one religious affiliation has permeated many aspects of life, starting with clothing - young girls are increasingly choosing to wear a hijab because of pressure from parents or peers. It is not uncommon to see young girls dressed in chadors: black dresses revealing only the eyes.

The last presidential election (April 2019) activated Islamic extremists. After Joko Widodo won again, the election results were disputed (Soeriaatmadja 2019). We also witnessed riots in the streets of Jakarta caused by supporters of the second candidate, Prabowo, who quite openly sympathizes with radical Islamic organizations. Extremist content heated up on the Internet - calls for jihad were heard. To deal with the disinformation and the increasing aggression, the Indonesian government had to limit access to social media, the main source of religious indoctrination in the country (Tehusijarana and Jessicha 2019). It is worth adding that Indonesians are the fourth largest group of Facebook users in the world, with 130 million accounts (Indonesia, fourth highest...).

A study commissioned by the Indonesian government shows a clear problem in universities: $20 \%$ of high school students and students on campuses support the creation of an Indonesian Caliphate ( 1 in 5 Indonesians... 2017). There are youth organizations on university campuses which, under changed names, pursue the goals of the outlawed Hizb ut-Tahrir party. 
One of my interlocutors admitted that these groups are accepted by university authorities as part of "religious tolerance". As a result of their fascination with conservative Islam, young people engage in a movement called hijrah. Hijrah, from the Arabic "journey, to migrate", for young Muslims in Indonesia means rebirth as a Muslim in "pure" Islam (Sunesti et al. 2018: 179). Involvement in hijrah is linked to major changes in life, not only in clothing but also in daily religious practices. Some more radical members promote polygamy as well as arranged marriages through social media.

After graduation, the majority of students involved in hijrah movements will most likely constitute an Indonesian middle class and implement their worldviews in their lives. In a survey conducted by Pew Research Center in 2017, $72 \%$ of respondents would like to see Sharia as official law in Indonesia (Lipka 2017). A report prepared by the independent Indonesian research centre Alavara in 2019 indicates that although respondents are open to having neighbors of different faiths, there is a growing tendency to limit contact with them (Indonesia moslem report...). The aversion to other religions results in a desire to set boundaries, to close oneself in a narrow group, and to highlight differences. All of these desires are justified in Indonesia by the fact that Muslims are the dominant majority, and religious minorities simply back down.

My Christian and Hindu interlocutors pointed out the helplessness in countering growing religious segregation. Moreover, Christian woman added, that it is better for them, especially in small towns, to keep their heads down. This approach points to the existing problem of "minority resignation" to maintain the status quo. The interlocutors emphasize the differences they have noticed over the years in how their neighbors treat their presence in a Muslimdominated neighborhood. The Hindu person admitted that he does not feel comfortable with having a Hindu shrine or devotional items in his garden. At the beginning of 2018 he decided to move all the items inside the house. When asked about perumahan syariah, interlocutors of different faiths initially nervously asked "What can we do about that?", thus revealing their irritation with the subject. They explained their nervousness and fear that such settlements would become commonplace. For them it would be equivalent to an exclusion from the neighborhood community they had lived in for many years. When asked if they were talking about their fears with their neighbors, everyone replied that they did not see any possibility to do so, and only talked about these topics with their nearest and dearest confidants. They also expressed their hopes that when the time comes, the development of such settlements will be stopped by central government and local authorities.

\section{PERUMAHAN ISLAM}

Indonesians are one of the most religious nations in the world. $99 \%$ of them admit that religion plays a very important role in their daily lives. For comparison, the percentage of people who think similarly in Egypt is $72 \%$ (The Age Gap in Religion...). Indonesian Muslims on the wave of the Middle East influx are looking for new ways to manifest their religious affiliation. They want to emphasize in every way their belonging to the Islamic world, not only by their appearance, but also by their lifestyle. Various types of new products and services 
have emerged from this demand, not only in terms of the fashion or beauty industry, but also architecture and the real estate market in general.

Among the first advertising campaigns targeting veiled Muslim women were advertisements for Sunsilk shampoo, which claimed to ensure that hair covered with a hijab stays fresh all day (Sunsilk...). Sunsilk's campaign has spurred a number of other halal products, including microwaves and refrigerators. Street vendors seeing the benefits of a halal food certificate apply for one, despite the high cost (Siregar 2019). On the wave of popularity of the Islamic lifestyle, the authorities in Jakarta decided to open a Halal Park, an area of almost $21000 \mathrm{~m}^{2}$ filled with shops offering certified products (Mufti 2019), not only food, but also clothes and cosmetics. The use of halal products is becoming a kind of fashion, which is also noticed by the leaders of Nahdlatul Ulama. They indicate that excessive obsession with this lifestyle can lead to numerous problems (Siregar 2019).

Specially designed products for Muslims have not only made religious expression easier, but they have also created an even greater need to accentuate Islamic faith. The unwillingness to have neighbors of a different faith, as well as the desire to emphasize their piety, make people look for places where they can live and raise their children in accordance with their own beliefs. Developers meet the expectations of the society and offer apartments in closed housing complexes in the so-called perumahan syariah, perumahan islam, kampung islam.

Complexes are built in cities or suburbs and offer varying features depending on their price, although highly characteristic is an entrance gate with a guard who monitors residents and guests. It is for this reason such settlements are called gated communities. In the literature, gated communities are defined as residential areas which:

- are surrounded by a wall or fence,

- have security systems including CCTV, security officers, or access cards, etc.,

- restrict access to public spaces (Blakey and Snyder 1997: 86).

Not all gated communities in Indonesia have all these characteristics. Very often the enclaves are not surrounded by a wall, but sometimes have one entrance road with a guardhouse and gate. It is worth mentioning that guardhouses at new housing estates are quite common in Indonesia, but in complexes openly promoted as "Muslim areas" they can play a slightly different role. Guardhouses are commonly empty, especially in less well-off neighborhoods, so their presence is contractual. Nevertheless, the local population is well aware of which neighborhoods are strictly Muslim and which are not.

Modern house design in Indonesia is more closely related to symbolism than functionality. Houses are not designed to fulfill the need of comfort or safety, but to display the prestige and lifestyle of their residents. The growing number of people interested in security and property protection is considered to be the reason behind gated communities. In addition, for the middle class it has become important to emphasize their social status as well as their modernity. Traditionally, gated communities have been associated with Chinese people, who are usually separated due to differences in standard of living and religion (Leisch 2002: 344). Construction of settlements in large areas began in Jakarta in the 1950s. By the year 2000, about 30 new towns had been established, the foundations of which were gated communities (Ginting and Sakinah 2018). 
Each of the settlements has its own mosque around which the lives of the inhabitants are centered. Residents are encouraged to engage in numerous religious activities and to follow Sharia rules, which are usually publicized by billboards. Residents should perform prayers five time per day, wear Islamic clothes and not smoke. Having a dog is strictly forbidden. In more conservative areas even watching TV or listening to music is not permitted. Moreover, women can be obligated to fully cover their faces. It is significant that most residents are associated with Muslim organizations or political parties (Weng 2014). The advertising slogan of one of the developers is "creating Heaven on Earth", although not open for everyone.

My four interlocutors stressed the importance of living in a closed housing complex. For them, pious Muslims, as they called themselves, it is of great value to be able to raise children according to their beliefs, among the people who share them. One of them expressed the belief that Muslims in Indonesia need more space than they so far have. From his statement, perumahan syariah meets his vision of a safe space for Muslims. Each person perceives himself or herself as tolerant of other faiths, but when asked whether he or she would agree to open a settlement for Christians or Hindus, if it were necessary, they agreed that this could only happen under serious circumstances such as a natural disaster. Their convictions, fueled by various media reports, deepen their sense of threat and need to protect Islam in Indonesia, even though no such threat exists. However, deepening Islamic conservatism with radical content may have a strong impact on the inhabitants of such settlements and encourage their further isolation and segregation.

\section{CONTROVERSY}

Developers offering apartments in perumahan syariah usually offer them under an Islamic mortgage. Although non-Muslims are allowed to use Islamic banking services, there are several hidden rules that effectively prevent them from buying a property in a complex. When buying a house, all personal documents must be presented, including a family card and an identity card, which in Indonesia indicates one's religious affiliation. Although no such information is officially disclosed, a religion other than Islam disqualifies a potential buyer. Such discrimination is against Indonesian law, but in the same time the legal tools to prevent it are clearly missing. At the beginning of 2019 journalists revealed many incidents of refusal to purchase a property on the grounds of a different religion (Syambudi 2019).

Following the publicity surrounding the many cases of refusal to purchase houses in Islamic neighborhoods, Sultan of Yogyakarta Hamengkubuwono X issued a decree on the prevention of social conflicts in April 2019 (Wickasono 2019). The Sultan's instructions concerned actions to efficiently and immediately minimize the risk of social conflicts on religious grounds. However, it is worrying that he is once again giving oversight of these issues to local leaders. It has been repeatedly reported that it was the village leaders who were involved in the process of purification of settlements, excluding those of other faiths (Syambudi 2019). The officials have committed themselves to comprehensive control of the developers and building permits issued to them. However, they admit that it is complicated on 
The crisis of religious intolerance in contemporary Indonesia...

many levels, also because, as they themselves point out, the demand for this type of housing derives directly from the society (Wickasono 2019). At such an early stage, it is not possible to verify the implementation of the regulations, but nevertheless their issue is an important gesture towards non-Muslims.

\section{CONCLUSION}

The growing number of products and services designed exclusively for Muslims is revealing a worrying and growing trend in Indonesian society. This paper takes as its lens perumahan syariah - a recent phenomenon which is vivid evidence of the crisis of intolerance in Indonesia. A social segregation trend based not only on financial status but also on religious affiliation is becoming more and more widespread. To emphasize or even exalt one's religiosity is today considered as part of a trendy lifestyle. Such practices are highly detrimental to the integrity of a multi-religious country. Muslims are the vast majority that set the tone not only for politics, but for society as a whole. Religious minorities are dangerously excluded from national discourse.

At the basic level, religious segregation leads to impoverishment or even to disappearance of relations between Muslim and non-Muslim neighbors. Lack of relations results in an accumulation of prejudices, misconceptions, and harmful stereotypes. This in turn can result in reluctance and in extreme cases even aggression. At the national level, the exclusion of certain groups, depriving them of their rights, as in the case of purchasing property in a closed housing complexes, may cause problems with state integrity. Moreover, it calls into question the democracy of the state, its pluralism, and its respect for human rights.

Islam is indeed infiltrating many aspects of Indonesians life more and more. It is visibly changing the cultural diversity, the meaning of citizenship, and people's relations with their neighbors and with the country, a democratic and after all secular state. The response of the authorities to the revealed cases of discrimination in Indonesia appears to be inadequate to mitigate the harm caused to these religious minorities. The lack of decisiveness and clear condemnation of such attitudes could lead to more serious violations of human rights and cause social tensions.

\section{REFERENCES}

1 in 5 Indonesian students support Islamic caliphate: Survey, https://www.straitstimes.com/ asia/se-asia/1-in-5-indonesian-students-support-islamic-caliphate-survey [17.01.2020].

Blakely, Edward and Mary Gail Snyder. 1997. Divided we fall: Gated and walled communities in the United States, in: Nan Ellin (ed.), Architecture of Fear, Princeton Architectural Press, pp. 85-99.

Diamant, Jeff. 2019. The countries with the 10 largest Christian populations and the 10 largest Muslim populations, https://www.pewresearch.org/fact-tank/2019/04/01/the-countries-with-the-10-largest-christian-populations-and-the-10-largest-muslim-populations/ [23.01.2020]. 
Ginting Wati, Salamina and R. Sakinah. 2018. Gated community in Indonesian peri-urban: security or segregation?, "IOP Conf. Series: Earth and Environmental Science", 202: 012-057.

Indonesia, fourth highest number of Facebook users in the world, https://www.thejakartapost. com/life/2018/03/04/indonesia-fourth-highest-number-of-facebook-users-in-the-world. html [15.01.2020].

Indonesia, https://www.cia.gov/library/publications/the-world-factbook/geos/id.html [10.01.2020].

Indonesia moslem report 2019: “The Challenges of Indonesia Moderate Moslems", http:// alvara-strategic.com/indonesia-muslim-report-2019/ [19.01.2020].

Kovacs, Amanda. 2014. Saudi Arabia Exporting Salafi Education and Radicalizing Indonesia's Muslims, https://www.giga-hamburg.de/de/publication/saudi-arabia-exporting-salafieducation-and-radicalizing-indonesia\%E2\%80\%99s-muslims [18.01.2020].

Leisch, Harald. 2002. Gated communities in Indonesia, "Cities", 19, 5, 341-350.

Lipka, Michael. 2017. Muslims and Islam: Key findings in the U.S. and around the world, https://www.pewresearch.org/fact-tank/2017/08/09/muslims-and-islam-key-findings-inthe-u-s-and-around-the-world/ [19.01.2020].

Llewellyn, Aisyah. 2019. Indonesian Buddhist woman's blasphemy conviction upheld, https:// www.aljazeera.com/news/2019/04/indonesian-buddhist-woman-blasphemy-convictionupheld-190408100321754.html [14.01.2020].

Mufti, Riza. 2019. Jokowi inaugurates Halal Park in Jakarta, https://www.thejakartapost.com/ news/2019/04/16/jokowi-inaugurates-halal-park-in-jakarta.html [20.01.2020].

Siregar, Kiki. 2019. From food to household appliances, Indonesia's new law on halal certification a boost for Islamic economy, https://www.channelnewsasia.com/news/asia/indonesia-halal-certificate-islamic-economy-household-appliances-12043814 [27.01.2020].

Soeriaatmadja, Wahyudi. 2019. Indonesian presidential candidate Prabowo rejects election result, vows to challenge it in Constitutional Court, https://www.straitstimes.com/asia/ se-asia/prabowo-after-defeat-says-will-not-accept-indonesia-election-result [17.01.2020].

Sunesti, Yuyun, Hasan Noorhaidi and Azca Muhammad. 2018. Young Salafi-niqabi and hijrah: agency and identity negotiation, "Indonesian Journal of Islam and Muslim Societies", 8, 2: 173-197.

Sunsilk website, https://www.sunsilk.com.my/hair-product-collections/hijab-recharge.html [25.01.2020].

Syambudi, Irwan. 2019. Perumahan Khusus Muslim dan Ancaman Toleransi di Yogyakarta, https://tirto.id/perumahan-khusus-muslim-dan-ancaman-toleransi-di-yogyakarta-dl1D [7.01.2020].

Tehusijarana, Karina M. and Valentina Jessicha. 2019. Jakarta riot: Government temporarily limits access to social media, messaging apps, https://www.thejakartapost.com/ life/2019/05/22/jakarta-riot-government-temporarily-limits-access-to-social-media-messaging-apps.html [12.01.2020].

The Age Gap in Religion Around the World, https://www.pewforum.org/2018/06/13/the-agegap-in-religion-around-the-world/ [20.01.2020]. 
Weng, Wai Hai. 2014. Making “new” Muslim Places in urban Malaysia and Indonesia, https:// www.iias.asia/sites/default/files/nwl_article/2019-05/IIAS_NL67_09.pdf [10.01.2020]. Wickasono, Pribadi. 2019. Yogyakarta Dicap Intoleran, Sultan HB X KeluarkanInstruksiIni, https://nasional.tempo.co/read/1192703/yogyakarta-dicap-intoleran-sultan-hb-X-keluarkan-instruksi-ini/full\&view=ok [20.01.2020].

\title{
KRYZYS TOLERANCJI RELIGIJNEJ WE WSPÓŁCZESNEJ INDONEZJI - FENOMEN MUZUŁMAŃSKIEGO RYNKU NIERUCHOMOŚCI I JEGO WPŁYW NA ŻYCIE SPOŁECZNE
}

\begin{abstract}
W ciągu ostatnich kilku lat Indonezja przeżywa religijne odrodzenie muzułmańskie. Oprócz rosnącej popularności konserwatywnych, a nawet radykalnych ideologii muzułmańskich, takich jak wahhabizm i salafizm, społeczeństwo de facto wieloreligijne stoi w obliczu silnego trendu segregacji religijnej. Indonezyjczycy poszukują nowych form manifestacji religijnej i wyrażania swojej pobożności. Jednym z najbardziej wyrazistych przykładów separacji muzułmanów od innych religii jest perumahan syariah - nowa forma zamkniętych osiedli w Indonezji. Artykuł opisuje narastające zjawisko zamkniętych dzielnic, gdzie życie mieszkańców jest regulowane przez prawo szariatu. W pierwszej części opisuję korzenie obecnego ożywienia religijnego i jego wpływ na sytuację społeczną. Następnie pogłębiam definicję zamkniętych wspólnot oraz kontrowersji związanych z tym tematem. W podsumowaniu przedstawiam możliwe implikacje tego fenomenu dla życia społecznego w Indonezji.
\end{abstract}

Słowa kluczowe: islam, Indonezja, zamknięte osiedla, antropologia, radykalizacja

Zgłoszenie artykułu: 10.02.2020

Recenzje: 21.03 .2020

Rewizja: 23.03 .2020

Akceptacja: 23.03 .2020

Publikacja on-line: 30.06 .2020 